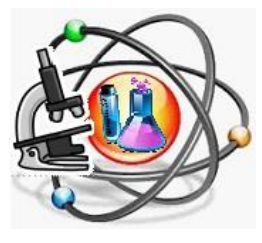

\title{
Reconstruction of E-Module of Circular Motion Based Guided Inquiry
}

\section{Rekontruksi E-Modul Gerak Melingkar Berbasis Inkuiri Terbimbing}

\author{
Suci Prihatiningtyas ${ }^{1 *}$, Siti Alimah $^{1}$ \\ ${ }^{1}$ Pendidikan FISIKA, Universitas KH. A. Wahab Hasbullah Jombang, Indonesia
}

This study aims to determine the feasibility of the e-Module Circular Motion Based Guided Inquiry. This research is a research development or Research and Development (R\&D) with the ADDIE model. The research instrument used was a validation sheet by the validator and student response questionnaires. The results of the validation sheet and student response questionnaires were assessed based on the Likert scale. The results of data analysis from the validation results of the $e$ Module Circular Motion Based on Guided Inquiry obtained a percentage of 92,02\%. This shows that in general the E-Module Circular Motion Based on Guided Inquiry that was developed is very feasible to be used in learning circular motion material in class X SMK. E-Module Circular Motion Based on Guided Inquiry is a medium that can attract the attention of students.

ISSN 25409859 (online)

Edited by: Noly Shofiyah

${ }^{*}$ Correspondence:

Suci Prihatiningtyas suciningtyas@unwaha.ac.id

Received:28-02-2021 Accepted: 21-05-2021 Published: 31-05-2021

Citation:

Prihatiningtyas $S$ and Alimah $S$ (2021) Reconstruction of E-Module of Circular Motion Based Guided Inquiry.

Science Education Journal (SEJ).

$$
\text { 5:1. }
$$

doi: $10.21070 /$ sej.v5i1.1295
Keywords: E-Module; Circular Motion; Guided Inquiry

Penelitian ini bertujuan untuk mengetahui kelayakan media E-Modul Gerak Melingkar Berbasis Inkuiri Terbimbing. Penelitian ini merupakan penelitian pengembangan atau Research and Development (R\&D) dengan model ADDIE. Instrumen penelitian yang digunakan berupa lembar validasi oleh validator dan angket respon peserta didik. Hasil lembar validasi dan angket respon peserta didik dinilai berdasarkan skala Likert. Hasil analisis data dari hasil validasi E-Modul Gerak Melingkar Berbasis Inkuiri Terbimbing diperoleh persentase sebesar 92,02\%. Hal ini menunjukkan bahwa secara keseluruhan E-Modul Gerak Melingkar Berbasis Inkuiri Terbimbing yang dikembangan sangat layak untuk digunakan dalam pembelajaran materi gerak melingkar pada kelas X SMK. E-Modul Gerak Melingkar Berbasis Inkuiri Terbimbing merupakan media yang dapat menarik perhatian peserta didik.

Kata Kunci: E-Modul; Gerak Melingkar; Inkuiri Terbimbing 


\section{PENDAHULUAN}

Penyebaran pandemi virus corona atau COVID-19 telah memberikan tantangan tersendiri bagi lembaga pendidikan di Indonesia. Untuk mengantisipasi penularan virus tersebut pemerintah mengeluarkan (Peraturan Menteri Kesehatan Republik Indonesia Nomor 9 Tahun 2020 Tentang Pedoman Pembatasan Sosial Berskala Besar Dalam Rangka Percepatan Penanganan Corona Virus Disease 2019 (Covid-19), 2020) seperti social distancing, physical distancing, hingga pembatasan sosial berskala besar (PSBB). Kondisi ini mengharuskan masyarakat untuk tetap diam di rumah, belajar, bekerja, dan beribadah di rumah. Akibat dari kebijakan tersebut membuat sektor pendidikan seperti sekolah maupun perguruan tinggi menghentikan proses pembelajaran secara tatap muka. Sebagai gantinya, proses pembelajaran dilaksanakan secara daring yang bisa dilaksanakan dari rumah masing-masing peserta didik.

Sesuai dengan (Surat Edaran Menteri Pendidikan Dan Kebudayaan Nomor 4 Tahun 2020 Tentang Pelaksanaan Kebijakan Pendidikan Dalam Masa Darurat Penyebaran Coronavirus Disease (Covid-19), 2020) (Kemendikbud. (2020)) menganjurkan untuk melaksanakan proses belajar dari rumah melalui pembelajaran daring. Kesiapan dari pihak penyedia layanan maupun peserta didik merupakan tuntutan dari pelaksanaan pembelajaran daring. Pelaksanaan pembelajaran daring ini memerlukan perangkat pendukung seperti komputer atau laptop, gawai, dan alat bantu lain sebagai perantara yang tentu saja harus terhubung dengan koneksi internet.

Dengan pelaksanaan pembelajaran secara daring, pendidik dituntut mampu membangun pembelajaran berbasis daring. Berdasarkan hasil observasi, model pembelajaran yang digunakan yakni melalui whatsapp (WA) dan google classroom (GC) dengan cara mengirimkan video atau powerpoint (PPT). Pada proses pembelajaran ini masih ditemukan beberapa permasalahan. Permasalahanpermasalahan tersebut yakni, (1) minat membaca peserta didik sangat rendah, (2) peserta didik malas untuk belajar, disamping itu peserta didik kurang termotivasi karena sumber belajar yang digunakan hanya berupa bahan bacaan, (3) modul yang diberikan cenderung berisi materi dan latihan soal saja sehingga membuat peserta didik kurang tertarik untuk membaca, (4) pendidik dalam menyampaikan materi hanya menggunakan slide powerpoint, kirim contoh video, dan bahkan hanya diberi tugas saja tanpa menyampaikan materi. Secara keseluruhan peserta didik kurang memahami materi.

Permasalahan tersebut harus segera dicarikan solusinya. Penggunaan bahan ajar yang dapat digunakan sebagai pegangan dalam belajar efektif, efisien dan mengutamakan kemandirian adalah bahan ajar berupa modul. (Prihatiningtyas et al. (2020)). Modul adalah sebuah buku yang ditulis dengan tujuan agar peserta didik dapat belajar secara mandiri tanpa atau dengan bimbingan guru, sehingga modul berisi paling tidak tentang segala komponen dasar bahan ajar, (Prihatiningtyas et al. (2020)), (Hamdi, Halim and Pontas. (2015)). Adapun modul yang sesuai dengan kondisi ini dan sesuai dengan perkembangan IPTEK adalah modul elektronik (e-Modul).

Modul elektronik (e-Modul) merupakan pilihan tepat untuk memudahkan guru dan peserta didik dalam menggunakan Teknologi Informasi dan Komunikasi (TIK) menjadi bermanfaat serta menunjang proses belajar mengajar. (Prihatiningtyas et al. (2020)). Modul elektronik (e-Modul) adalah modul versi elektronik dimana akses dan penggunaannya dilakukan melalui alat elektronik seperti komputer, laptop, tablet, atau bahkan smartphone. Tulisan yang ada pada $e$-Modul dapat diketik menggunakan Microsoft Word kemudian dikonversi ke dalam bentuk $p d f$ dan ditampilkan dalam program $e$-Modul khusus seperti Flipbook Maker. Adapun kelebihan $e$-Modul dibandingkan media cetak yaitu $e$-Modul dilengkapi dengan media interaktif seperti video, audio, animasi dan fitur interaktif lain yang dapat dimainkan dan diputar ulang saat menggunakan $e$-Modul. $e$ Modul dinilai bersifat inovatif karena dapat menampilkan bahan ajar yang lengkap, menarik, interaktif, dan mengemban fungsi kognitif yang bagus, (Prihatiningtyas et al. (2020)), dan (Siregar et al. (2017)).

Proses pembelajaran yang akan dilakukan adalah menggunakan model pembelajaran berbasis inkuiri terbimbing. Inkuiri terbimbing merupakan model pembelajaran yang dapat meningkatkan hasil belajar peserta didik dengan merancang dan menemukan sendiri konsepkonsep fisika yang akan membuat materi tersebut lebih lama tersimpan dalam ingatan peserta didik. Pada Inkuiri Terbimbing peran peserta didik lebih dominan dan lebih aktif. Sedangkan guru mengarahkan dan membimbing peserta didik ke arah yang tepat atau benar, (Mulawarman. (2015)), (Sumarni et al. (2017)). Pembelajaran inkuiri terbimbing diterapkan agar peserta didik bebas mengembangkan konsep yang mereka pelajari. Peserta didik diberi kesempatan untuk memecahkan masalah yang mereka hadapi secara individu atau kelompok, peserta didik juga dilatih untuk berinteraksi dengan teman sebayanya untuk saling bertukar informasi. (Sumarni et al. (2017)).

Berdasarkan pernyataan di atas, maka tujuan penelitian ini untuk mengetahui kelayakan media $e$-Modul Gerak Melingkar Berbasis Inkuiri Terbimbing. Harapan peneliti dengan adanya media ini, dapat digunakan sebagai penunjang dalam penyampaian materi selama pembelajaran daring sehingga peserta didik dapat termotivasi dalam belajar mandiri dan lebih memahami materi yang disampaikan.

\section{METODE PENELITIAN}

Penelitian ini menggunakan metode penelitian dan pengembangan (Researchs and Development/R \& D). Model pengembangan yang digunakan adalah ADDIE, yaitu: Analysis (Analisis), Design (Desain), Develop (Pengembangan), Implement (Implementasi), dan Evaluate (Evaluasi). Instrumen penelitian yang digunakan berupa lembar kelayakan dan angket respon peserta didik. Hasil lembar kelayakan dan angket respon peserta didik dinilai berdasarkan skala Likert. 
Teknik analisis data:

1. Analisis Kelayakan $e$-Modul

Hasil analisis yang diperoleh dari kata kuantitatif dan kualitatif digunakan sebagai acuhan dalam menentukan kelayakan media hasil pengembangan. Angket yang digunakan dalam analisis data kuantitatif ini menggunakan skala Likert. Adapun kriteria skor dengan skala Likert yang dijelaskan oleh (Prihatiningtyas et al. (2020)) dapat dilihat pada Tabel 1.

\section{[Table 1 about here]}

Data yang terkumpul dianalisis dengan teknik analisis deskriptif kuantitatif yang diungkapkan dalam distribusi skor dan persentase terhadap kategori skala penilaian yang telah ditentukan. Setelah penyajian dalam bentuk persentase, langkah selanjutnya mendeskriptifkan dan mengambil kesimpulan tentang masing-masing indikator. Jenjang kualifikasi kriteria kelayakan untuk menyimpulkan hasil validasi pengembangan media pembelajaran dapat menggunakan seperti Tabel 2 berikut ini:

\section{[Table 2 about here]}

2. Analisis respons peserta didik

Data hasil respons yang diberikan kepada peserta didik dianalisis dengan menggunakan statistik deskriptif dengan persentase. Persentase respons peserta didik dihitung dengan rumus:

$$
\% \text { respon }=\frac{\text { skor respon yang diperoleh }}{\text { skor maksimum respon }} \times 100 \%
$$

Analisis respon peserta didik, setelah persentase didapat kemudian mencocokan ke dalam kriteria pedoman penilaian yang telah dibuat sesuai dengan $\underline{\text { Tabel } 3}$.

$$
\text { [Table } 3 \text { about here] }
$$

\section{HASIL DAN PEMBAHASAN}

Hasil penelitian pengembangan $e$-Modul Gerak Melingkar Berbasis Inkuiri Terbimbing menggunakan Model ADDIE secara lengkap dipaparkan sebagai berikut:

\section{Analysis (Analisis)}

Pada tahap ini bertujuan untuk menganalisis syarat-syarat pengembangan produk yang sesuai dengan kebutuhan pengguna. Analisis materi dilakukan dengan cara mengumpulkan materi-materi yang relevan berasal dari modul, buku, internet. Analisis karakteristik peserta didik bertujuan untuk menelaah karakteristik peserta didik yang sesuai dengan rancangan dan pengembangan media pembelajaran. Karakteristik meliputi perkembangan kognitif peserta didik baik kelompok atau individu dan latar belakang pengetahuan. Sebelum pembuatan $e$-Modul Gerak Melingkar Berbasis Inkuiri Terbimbing, tujuan pembelajaran dan kompetensi yang hendak diajarkan perlu dirumuskan terlebih dahulu. Hal ini dilakukan agar peneliti dapat membatasi penelitian agar tidak menyimpang dari tujuan semula. Perumusan tujuan berdasarkan kompetensi inti dan kompetensi dasar yang sesuai dengan kurikulum 2013.

\section{Design (Perancangan)}

Pada tahap design e-Modul Gerak Melingkar Berbasis Inkuiri Terbimbing, peneliti membuat produk awal atau rancangan produk yang akan dikembangkan yang terdiri dari tahapan: penyusunan draf $e$-Modul, menyiapkan komponen pendukung yaitu Flipbook PDF professional, membuat $e$ Modul yang mencakup cover, pendahuluan, capaian pembelajaran/kemampuan akhir yang direncanakan, indikator, materi gerak melingkar, contoh soal dan penyelesaiannya, latihan soal pada tiap sub materi, lembar kerja peserta didik, rangkuman dan uji kompetensi. Setelah melalui tahap pengeditan, file $e$-Modul yang sudah tersimpan dalam bentuk .pdf. akan di masukkan ke dalam aplikasi Flipbook PDF professional.

Desain $e$-Modul materi Gerak Melingkar dapat dibagi menjadi tiga bagian yaitu bagian depan meliputi halaman sampul, pendahuluan, kompetensi inti, kompetensi dasar, indikator pencapaian kompetensi, tujuan pembelajaran dan peta konsep yang dapat dilihat pada Gambar $\underline{1}$.

\section{[Figure 1 about here]}

Bagian kedua merupakan isi dari $e$-Modul meliputi materi sesuai dengan tahapan inkuiri terbimbing, sekilas info dan galeri karya seperti yang ditunjukkan Gambar 2. Bagian isi berisi materi, contoh soal dan pembahasan, gambar dan video yang berhubungan dengan materi.

\section{[Figure 2 about here]}

Bagian ketiga merupakan penutup $e$-Modul yang berisi rangkuman, uji kompetensi, dan daftar pustaka yang dapat dilihat pada Gambar $\underline{3}$.

\section{[Figure 3 about here]}

Desain secara lengkap dapat dilihat dalam website: https://online.flipbuilder.com/uteyx/rhvg/

\section{Development (pengembangan)}

Pada tahap Development, e-Modul Gerak Melingkar Berbasis Inkuiri Terbimbing yang sudah dikembangkan akan divalidasi oleh para ahli untuk mengetahui kelayakan berdasarkan penilaian: 1) ahli materi yang berkompeten di bidang pendidikan fisika; 2) ahli media yang berkompeten dalam bidang media pembelajaran interaktif. Para ahli akan menilai serta memberikan komentar maupun saran yang berguna untuk membuat $e$-Modul Gerak Melingkar Berbasis Inkuiri Terbimbing menjadi lebih baik lagi. Hasil kelayakan dari validator disajikan pada Gambar $\underline{4}$.

\section{[Figure 4 about here]}

Berdasarkan Gambar $\underline{4}$ bahwa aspek penilaian pada ahli 
materi (validasi materi) ada empat yaitu kelayakan isi, kelayakan penyajian, kelayakan bahasa menurut BSNP, dan penilaian kontekstual dengan persentase rata-rata yang diberikan oleh keempat validator yaitu 91,90\%. Hal ini dikarenakan penyampaian materi sudah runtut dan jelas, materi yang disampaikan disesuaikan dengan kompetensi dasar, kompetensi inti dan indikator pembelajaran yang sesuai dengan kurikulum 2013 sehingga urutan materi tiap subbab sudah runtut.

E-Modul Gerak Melingkar Berbasis Inkuiri Terbimbing yang dikembangkan mencakup aspek yang terdapat pada inkuiri terbimbing yaitu orientasi, rumusan hipotesis, definisi, eksplorasi, pembuktian dan perumusan generalisasi. Pada $e$-Modul Gerak Melingkar Berbasis Inkuiri Terbimbing permasalahan yang dikaji merupakan permasalahan berhubungan gerak melingkar yang dihadapi oleh peserta didik dalam kehidupan sehari-hari. Masalah yang dikaji kemudian diselesaikan melalui pencarian informasi (membaca $e$-Modul Gerak Melingkar Berbasis Inkuiri Terbimbing) untuk menjelaskan dan memecahkan masalah dari fenomena alam. Kemudian, kegiatan memecahkan permasalahan dapat mengembangkan kompetensi literasi sains peserta didik berupa kemampuan untuk menarik kesimpulan berdasarkan bukti-bukti yang ilmiah. Hal ini sejalan dengan pendapat (Sudjana, N. (2005)), menyatakan bahwa peserta didik yang memiliki kemampuan dalam menggunakan bukti ilmiah dan menjelaskan tentang fenomena alam dapat semakin berkembang melalui kegiatan diskusi kelas yang difasilitasi oleh guru sehingga peserta didik dapat menyampaikan pendapat secara lisan dan tulisan berdasarkan temuan peserta didik tersebut.

Aspek penilaian pada media (Validasi media) ada 3 yaitu ukuran $e$-Modul, desain sampul $e$-Modul, dan desain isi $e$ Modul, persentase rata-rata yang diberikan oleh keempat validator yaitu 92,18\%. Aspek desain disesuaikan dengan perkembangan teknologi dan disesuaikan dengan karakteristik peserta didik yaitu desain yang tidak terlalu kaku seperti pada $e$-Modul sebelumnya atau seperti modul cetak. Aspek desaian dibuat semenarik mungkin sehingga peserta didik tertarik untuk membaca. Desain warna-warna di tiap halaman yang menarik dengan kombinasi yang pas, terdapat video pembelajaran terkait materi yang dibahas, materi yang dibahas dihubungkan langsung dengan peristiwa yang sering dijumpai dalam kehidupan sehari-hari serta ditampilkan dengan persamaannya juga sehingga membuat pembaca langsung memahami maksud yang ingin disampaikan dalam $e$-Modul.

Aspek konten yang terdapat pada $e$-Modul yaitu terdapat kesesuaian dalam pemilihan background yang sesuai tema gerak melingkar, pemilihan ukuran dan jenis ukuran yang konsisten sehingga mudah dibaca, pemilihan warna yang menarik, gambar sesuai dengan tema dan terdapat video sebagai pendukung dalam penjelasan materi. Aspek konten disesuaikan dengan langkah-langkah pembelajaran berbasis inkuiri terbimbing, terdapat penjelasan materi disertai gambar, menu sekilas info yang berisi tentang video yang berkaitan dengan gerak melingkar dalam kehidupan sehari- hari, galeri karya berisi kegiatan percobaan dan pembuatan alat peraga yang berhubungan dengan gerak melingkar, terdapat kegiatan praktikum yang menunjang pembelajaran berbasis inkuiri terbimbing. Aspek organisasi, bahasa dan keterbacaan, isi $e$-Modul disesuaikan dengan kejadian yang dialami dalam kehidupan sehari-hari, bahasa mudah dipahami dan tidak menimbulkan makna ganda dan pengorganisasian $e$ Modul teratur dan runtut.

Secara keseluruhan validator memberikan nilai 92,02\% yang berarti $e$-Modul yang dikembangkan sangat layak digunakan dengan revisi. Hal ini sejalan dengan penelitian Imansari and Sunaryantiningsih (2017)) yang mengatakan bahwa media pembelajaran $e$-Modul interaktif yang dibuat telah layak untuk digunakan pada proses belajar mengajar di kelas, hasil belajar mahasiswa yang menggunakan media $e$ Modul interaktif dinyatakan tuntas, respon mahasiswa terhadap penggunaan media $e$-Modul interaktif pada proses pembelajaran juga masuk pada kategori baik. Begitu pula dengan hasil penelitian (Laili, (2019)) yang menyatakan $e$ Modul project based learning dikatakan efektif dinilai dari aspek psikomotor. Menurut (Tania. (2017)) juga menyatakan bahwa pengembangan $e$-Modul berbasis website layak digunakan sebagai media pembelajaran fisika SMA dengan kategori secara umum sangat baik dan dapat meningkatkan pencapaian kompetensi pengetahuan fisika SMA.

Hal ini didukung oleh penelitian Ramadhona yang mengatakan bahwa dalam pembuatan media pembelajaran harus disesuaikan dengan tujuan pembelajaran, materi ajar dan juga karakteristik peserta didik sebagai subjek belajar. Penggunaan media sebagai alat pendukung penguasaan kompetensi literasi sains dan kompetensi abad 21 dapat memainkan peranan pentingnya apabila dijadikan sebagai alat berpikir kritis dan digunakan dalam kegiatan inkuiri yang dilakukan oleh peserta didik.

\section{Implementation (implementasi)}

Tahap implementasi dilakukan dengan cara pendidik menyampaikan materi di kelas menggunakan $e$-Modul Gerak Melingkar Berbasis Inkuiri Terbimbing yang sudah divalidasi. Setelah itu pendidik memberikan angket respon kepada peserta didik melalui google form (GF). Implementasi dilakukan pada peserta didik kelas X SMK Sunan Ampel Jombang.

\section{Evaluation (Evaluasi)}

Evaluasi dilakukan untuk melihat apakah media pembelajaran $e$-Modul Gerak Melingkar Berbasis Inkuiri Terbimbing sesuai harapan awal atau tidak. Evaluasi diperoleh dari hasil respon peserta didik setelah menggunakan media pembelajaran $e$-Modul Gerak Melingkar Berbasis Inkuiri Terbimbing.

Respon peserta didik diperoleh dari hasil pengisian angket respon melalui google form (GF). Setelah membaca respon peserta didik secara garis besar dapat dibuat grafik seperti yang ditunjukkan pada Tabel $\underline{4}$.

[Table 4 about here] 
Berdasarkan Tabel $\underline{4}$ secara keseluruhan peserta didik memberikan respon sangat baik dengan persentase rata-rata sebesar 91,2\% terhadap $e$-Modul yang dikembangkan. Persentase tersebut jika dilihat pada Tabel $\underline{4}$ termasuk kategori sangat baik. Hal ini menunjukkan peserta didik senang dengan $e$-Modul yang dikembangkan. Apabila dilihat dari aspek materi yang ditampilkan pada $e$-Modul jelas, runtut, mudah dipahami dan materi yang disajikan sesuai dengan kurikulum. Pada aspek manfaat, terbukti bahwa menggunakan $e$-Modul mudah dipahami, memberikan pengalaman belajar baru, mudah digunakan. Pada aspek penggunaan, $e$-Modul dapat digunakan kapan saja, dimana saja, dapat digunakan belajar mandiri maupun klasikal.

Pada aspek kesesuaian media, yang dimaksud adalah isi $e$-Modul menunjukkan semua kejadian terkait gerak, durasi waktu dalam video tidak terlalu lama dan tidak terlalu cepat sehingga peserta didik tidak bosan, pembahasan materi yang digunakan sesuai dengan bahasa sehari-hari sehingga mudah dipahami. Pada aspek visual, $e$-Modul memiliki tampilan yang menarik, memiliki kualitas gambar yang bagus, teks dapat terbaca karena ukuran hurufnya disesuaikan, tata letaknya tepat sehingga $e$-Modul yang dihasilkan dari segi visual sangat menarik minat pembaca. Pada aspek audio, terdengar jelas begitu juga untuk sound effect.

Hal ini juga didukung oleh pendapat (Wulansari et al., (2018)) yang mengatakan bahwa $e$-Modul yang dikembangkan berbeda dengan sumber belajar yang mereka gunakan sebelumnya. Pendapat (Tania. (2017)) menyebutkan bahwa bahan ajar interaktif dimanfaatkan karena menarik dan memudahkan penggunanya dalam mempelajari materi.

\section{KESIMPULAN}

Berdasarkan penelitian yang dilakukan maka dapat disimpulkan bahwa $E$-Modul berbasis inkuiri terbimbing menggunakan model ADDIE yang dikembangkan layak digunakan dengan revisi dengan persentase rata-rata yang diberikan oleh validator sebesar 92,02\%. Ditinjau dari aspek materi, media ini termasuk dalam kualifikasi/predikat sangat baik, dengan persentase tingkat pencapaian $91,90 \%$ dan ditinjau dari aspek media, media ini termasuk dalam kualifikasi/predikat sangat baik, dengan persentase $92,18 \%$. Selain itu, keseluruhan peserta didik memberikan respon sangat baik dengan persentase rata-rata sebesar 91,2\% terhadap $e$-Modul berbasis inkuiri terbimbing yang dikembangkan.

\section{UCAPAN TERIMA KASIH}

Terimakasih kepada dosen prodi pendidikan fisika Unwaha dan seluruh civitas akademika Universitas KH. A. Wahab Hasbullah.

\section{REFERENCES}

Hamdi, Halim, A., \& Pontas, K. (2015). Pendidikan Mipa Fkip Unigha Sigli. 03(02), 22-34. https://journal.unismuh.ac.id/index.php/jpf/article/view/3442

Imansari, N., \& Sunaryantiningsih, I. (2017). Pengaruh Penggunaan E-Modul Interaktif Terhadap Hasil Belajar Mahasiswa pada Materi Kesehatan dan Keselamatan Kerja. VOLT: Jurnal Ilmiah Pendidikan Teknik Elektro, 2(1),
11-16. https://doi.org/10.30870/volt.v2i1.1478

Laili, I. (2019). Efektivitas Pengembangan E-Modul Project Based Learning Pada Mata Pelajaran Instalasi. Jurnal Imiah Pendidikan dan Pembelajaran, 3, 306315.

https://ejournal.undiksha.ac.id/index.php/JIPP/article/download/21840/13513

Mulawarman, U. (2015). Pengaruh Model Pembelajaran Inkuiri Terbimbing ( Guided Inquiry ) Dan Motivasi Terhadap Hasil Belajar Fisika Siswa Program Studi Pendidikan Fisika Fakultas Keguruan dan Ilmu Pendidikan pembelajaran yang berpusat pada siswa. Namun kenyataannya kegiatan be. 18(1), 49-63.

Peraturan menteri kesehatan republik indonesia nomor 9 tahun 2020 tentang pedoman pembatasan sosial berskala besar dalam rangka percepatan penanganan corona virus disease 2019 (covid-19), 1 (2020).

Prihatiningtyas, S., Fatikhatun, ), Sholihah, N., Universitas, ), Wahab Hasbullah, K. A., Garuda, J., 09, N., \& Jombang, T. (2020). Jurnal Pendidikan Fisika Universitas Muhammadiyah Makassar Project Based Learning E-Module to Teach Straight-Motion Material for Prospective Physics Teachers. Jurnal Pendidikan Fisika, 8(3), 223-234. https://doi.org/10.26618/jpf.v8i3.3442

Ramadhona, S. F., Caska, C., \& Trisnawati, F. Pengaruh Penggunaan Media Pembelajaran Animasi terhadap Minat dan Hasil Belajar Siswa pada Mata Pelajaran Ekonomi di Kelas X Jurusan IPS SMA Negeri 1 Kundur (Doctoral dissertation, Riau University)Sari, Rahmi maiyunda, Rusdi, Maulidiya, D. (2019). Penerapan Model Pembelajaran Inkuiri Terbimbing Untuk Meningkatkan Aktivitas Matematika Peserta Didik Kelas VII SMP Negeri 2 Kota Bengkulu. Jurnal Penelitian Pembelajaran Matematika Sekolah, 3(1), $31-39$.

Siregar, L. R., Harlin, \& Syofii, I. (2017). Pengembangan Media Pembelajaran Modul Elektronik Mata Kuliah Diagnosis Kendaraan di Program Studi Pendidikan Teknik Mesin Universitas Sriwajaya. Jurnal Pendidikan Teknik Mesin, 4(1), 45-50.

Sudjana, N. (2005). Metode statistika. Bandung: Tarsito, 168

Sumarni, S., Santoso, B. B., \& Suparman, A. R. (2017). Model Pembelajaran Inkuiri Terhadap Hasil Belajar Kognitif Peserta Didik di SMA ( Studi Pada Pokok Bahasan Kelarutan dan Hasil Kali Kelarutan ) The Effect Of Guided Inquiry Learning Model To The Cognitive Achievement Of Students In SMA Negeri 01 Manokwari. Jurnal Nalar Pendidikan, 5(1), 21-30.

Suryaningsih, Ni Made Ayu, Cahaya, I Made Elia, Poerwati, C. E. (2016). Implementasi Pembelajaran Inkuiri Terbimbing Berbasis Permainan Dalam Meningkatkan Kreativitas Anak Usia Dini. Pendidikan Indonesia, 5(2), 212220.

Tania, L. (2017). Pengembangan Bahan Ajar E-Modul Sebagai Pendukung Pembelajaran Kurikulum 2013 pada Materi Ayat Jurnal Penyesuaian Perusahaan Jasa Siswa Kelas X Akuntansi Smk Negeri 1 Surabaya. Jurnal Pendidikan Akuntansi (JPAK), 5(2), 1-9.

Wulansari, E. W., Kantun, S., \& Suharso, P. (2018). Pengembangan E-Modul Pembelajaran Ekonomi Materi Pasar Modal Untuk Siswa Kelas XI IPS MAN 1 Jember Tahun Ajaran 2016/2017. Jurnal Pendidikan Ekonomi: Jurnal Ilmiah Ilmu Pendidikan, Ilmu Ekonomi dan Ilmu Sosial, 12(1), 1-7. https://doi.org/10.19184/jpe.v12i1.6463

Conflict of Interest Statement: Theauthors declare that the research was conducted in the absence of any commercial or financial relationships that could be construed as a potential conflict of interest.

Copyright (c) 2021 Prihatiningtyas S and Alimah S. This is an open-access article distributed under the terms of the Creative Commons Attribution License (CC $B Y)$. The use, dis- tributionorreproduction inotherforums is permitted, provided the original author(s) and the copyright owner(s) are credited and that the original publication in this jour- nal is cited, in accordance with accepted academic practice. No use, distribution or reproduction is permitted which does not comply with these terms. 


\section{LIST OF TABLE}

1. Pedoman Penilaian Kategori Skala Likert

2. Konversi Tingkat Pencapaian (Prihatiningtyas et al., 2020) .........................................................................66

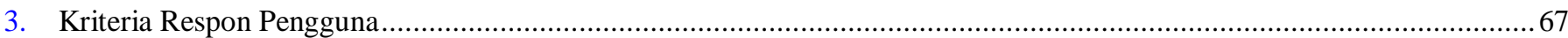

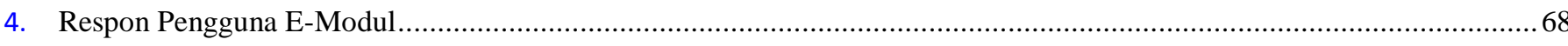


Tabel 1/ Pedoman Penilaian Kategori Skala Likert

Penilaian

Sangat Valid/layak

Nilai

Valid/layak

Kurang Valid/layak

Tidak Valid/layak

4

3 
Tabel 2. Konversi Tingkat Pencapaian (Prihatiningtyas et al., 2020)

Tingkat Ketercapaian Kualifikasi

$90 \%-100 \%$

$75 \%-89 \%$

$65 \%-74 \%$

$55 \%-64 \%$

Sangat Layak

Layak

Keterangan

Tidak perlu revisi

$0 \%-54 \%$

Cukup Layak

Direvisi

Direvis

Kurang Layak Direvisi

Tidak Layak

Direvis 
Tabel 3. Kriteria Respon Pengguna

\begin{tabular}{llll}
\hline Persentase & Nilai huruf & Bobot & Predikat \\
$86 \%-100 \%$ & A & 4 & Sangat Baik \\
$76 \%-85 \%$ & B & 3 & Baik \\
$60 \%-75 \%$ & C & 2 & Cukup Baik \\
$55 \%-59 \%$ & D & 1 & Kurang Baik \\
$0 \%-54 \%$ & E & 0 & Tidak Baik \\
\hline
\end{tabular}




\begin{tabular}{|c|c|c|c|c|}
\hline Aspek & Indikator & $\begin{array}{l}\text { Persentase } \\
(\%)\end{array}$ & $\begin{array}{l}\text { Persentase rata-rata } \\
\text { Tiap Aspek }(\%)\end{array}$ & Kategori \\
\hline \multirow{3}{*}{ Materi } & Kejelasan Materi Pendahuluan & 90,7 & \multirow{4}{*}{90,5} & \multirow{4}{*}{ Sangat Baik } \\
\hline & Materi sesuai $\mathrm{KD}, \mathrm{KI}$, dan Indikator & 91,4 & & \\
\hline & Keruntutan Penyajian Materi & 90,7 & & \\
\hline \multirow{5}{*}{ Manfaat } & Jendela sains dan cerita sesuai dengan materi & 89,3 & & \\
\hline & Mudah dipahami & 92,9 & \multirow{4}{*}{90,9} & \multirow{5}{*}{ Sangat Baik } \\
\hline & Memberi pengalaman belajar baru & 90,0 & & \\
\hline & Kemudahan penggunaan & 90,4 & & \\
\hline & Menumbuhkan kemampuan literasi & 90,4 & & \\
\hline \multirow{3}{*}{ Penggunaan } & Dapat digunakan kapan saja & 88,9 & \multirow{5}{*}{91,0} & \\
\hline & Dapat digunakan dimana saja & 92,9 & & \multirow[t]{4}{*}{ Sangat Baik } \\
\hline & Dapat digunakan untuk belajar mandiri & 91,4 & & \\
\hline \multirow{7}{*}{$\begin{array}{l}\text { Kesesuaian } \\
\text { Media }\end{array}$} & Dapat digunakan secara klasikal & 90,7 & & \\
\hline & Kesesuaian isi e-Modul dengan materi & 91,4 & & \\
\hline & Durasi video dalam e-modul cukup & 90,0 & \multirow{5}{*}{91,0} & \multirow{5}{*}{ Sangat Baik } \\
\hline & Ketepatan penggunaan bahasa & 92,1 & & \\
\hline & Kesesuaian jendela sains dengan e-modul & 90,4 & & \\
\hline & Tipografi & 91,1 & & \\
\hline & Kualitas gambar & 93,9 & & \\
\hline \multirow[t]{3}{*}{ Visual } & Keterbacaan teks & 93,2 & \multirow[t]{3}{*}{92,4} & \multirow[t]{3}{*}{ Sangat Baik } \\
\hline & Kesesuaian warna huruf & 92,9 & & \\
\hline & Tata letak (lay out) & 90,7 & & \\
\hline \multirow[t]{3}{*}{ Audio } & Kejelasan suara dalam video & 92,5 & \multirow{2}{*}{91,0} & \multirow[t]{2}{*}{ Sangat Baik } \\
\hline & Ketepatan penggunaan sound effect & 89,3 & & \\
\hline & Rata-rata & & 91,2 & Sangat Baik \\
\hline
\end{tabular}




\section{LIST OF FIGURE}

1. Bagian depan $e$-Modul meliputi halaman sampul, pendahuluan, kompetensi inti, kompetensi dasar, indikator pencapaian kompetensi, tujuan pembelajaran, dan peta konsep.

2. Bagian isi $e$-Modul meliputi materi gerak melingkar, sekilas info dan galeri karya ...................................................66

3. Bagian penutup $e$-Modul yang berisi rangkuman, uji kompetensi, daftar pustaka, dan biografi penulis........................... 67

4. Hasil Uji Kelayakan $e$-Modul Gerak Melingkar Berbasis Inkuiri Terbimbing...... .68 


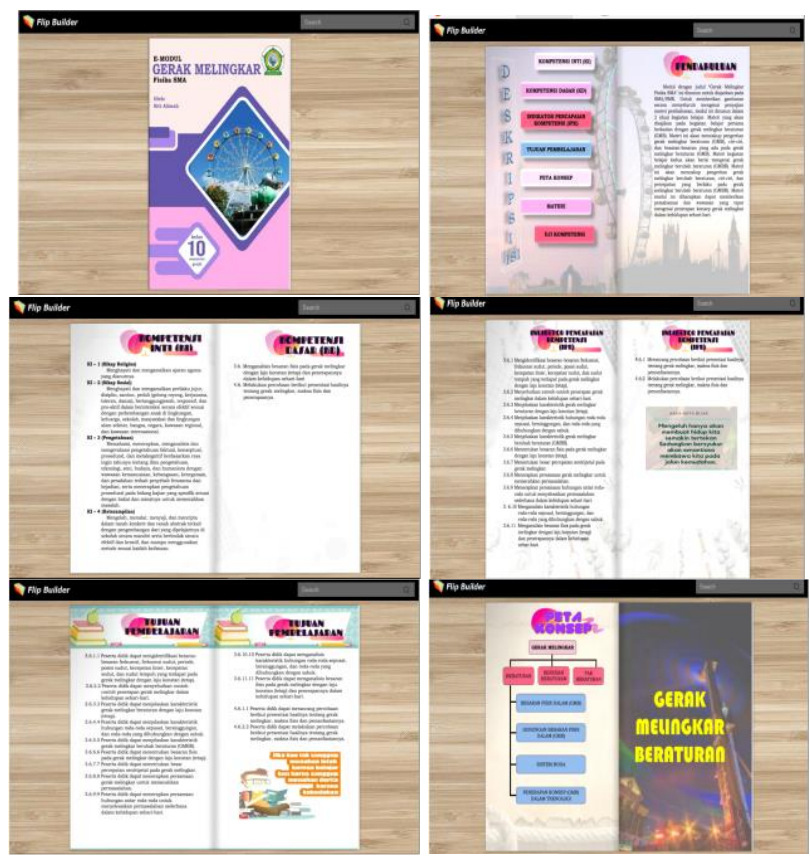

Gambar 1. Bagian depan $e$-Modul meliputi halaman sampul, pendahuluan, kompetensi inti, kompetensi dasar, indikator pencapaian kompetensi, tujuan pembelajaran, dan peta konsep 

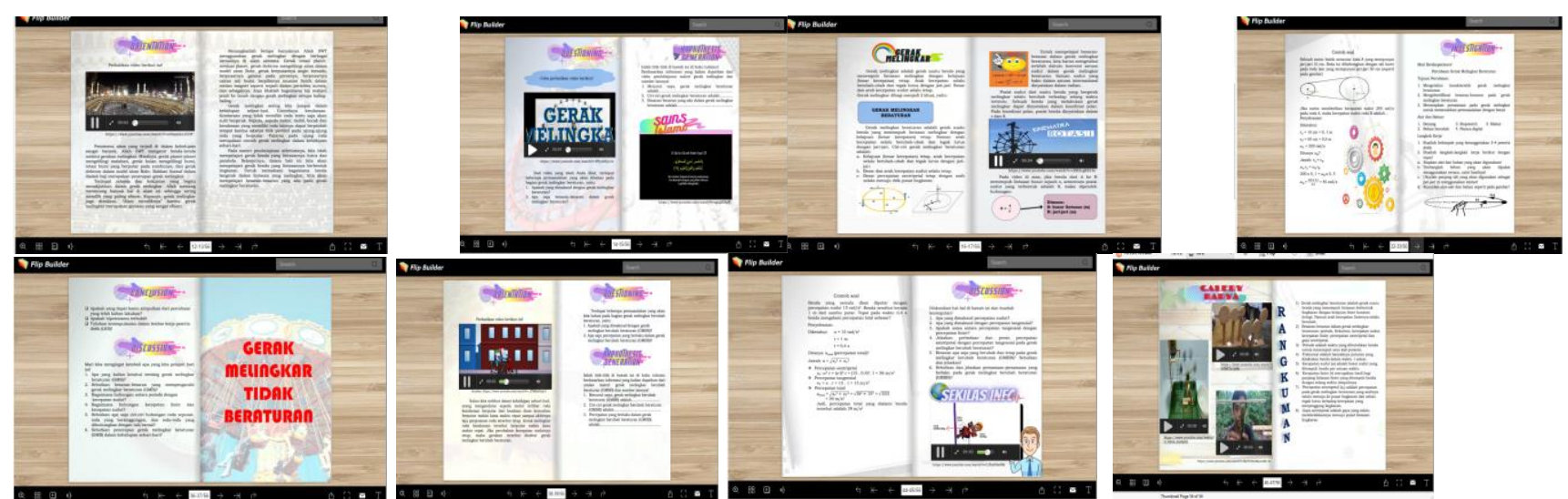

Gambar 2. Bagian isi $e$-Modul meliputi materi gerak melingkar, sekilas info dan galeri karya 


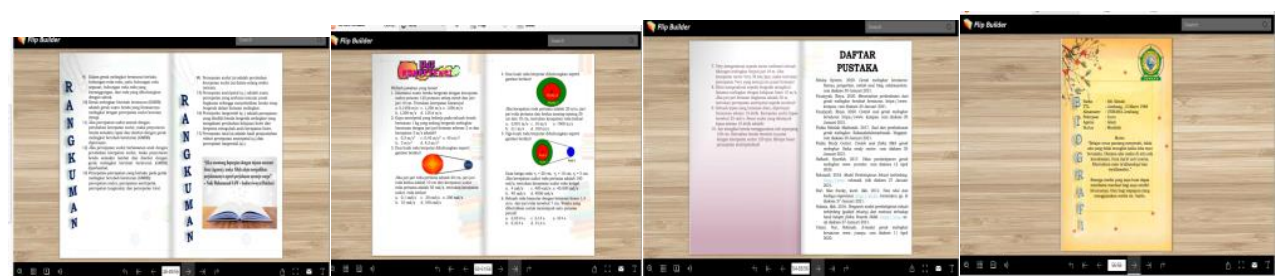

Gambar 3. Bagian penutup $e$-Modul yang berisi rangkuman, uji kompetensi, daftar pustaka, dan biografi penulis. 


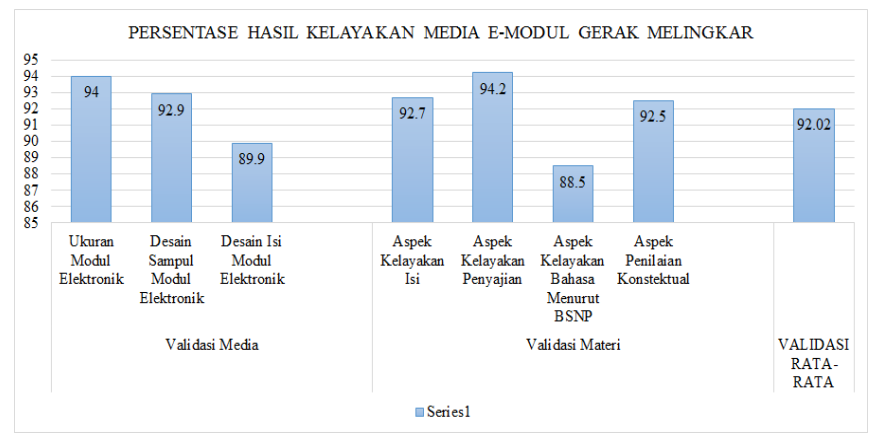

Gambar 4. Hasil Uji Kelayakan e-Modul Gerak Melingkar Berbasis Inkuiri Terbimbing 